\title{
'Real' fall in US research funding revealed
}

[WASHINGTON] US spending on research and development (R\&D) has fallen by 5 per cent since 1994, considerably more than the 2 per cent drop acknowledged by the Clinton administration, according to the National Academy of Sciences.

But the shrinkage has been concealed in official statistics which include non-research items - such as the testing and evaluation of weapons systems - in the official $R \& D$ budget.

The new figure emerges from a reassessment by the academy of total US spending on $\mathrm{R} \& \mathrm{D}$. By excluding non-innovative spending, chiefly at the Department of Defense, the academy comes up with what it considers to be a more accurate measure of expenditure, which it calls Federal Science and Technology (FS\&T).

The reassessment follows the publication in 1995 of the report of a panel chaired by Frank Press, a former president of the academy, calling on the administration and the Congress to start counting R\&D on this new basis (see Nature 378, 426; 1995). The call was ignored, but the academy decided to publish the new measure anyway, in the hope that it will gain currency and authority.

The first assessment finds that FS\&T funding in the 1997 financial year (which began on 1 October 1996) will be $\$ 43.4$ billion, and that this represents a drop of 5 per cent in spending power since 1994. In the same period, total R\&D spending, as measured by the federal government, fell by 2 per cent to $\$ 74$ billion.

Press - who was science adviser to President Jimmy Carter - says that the new assessment reveals for the first time the extent to which support for science and tech-

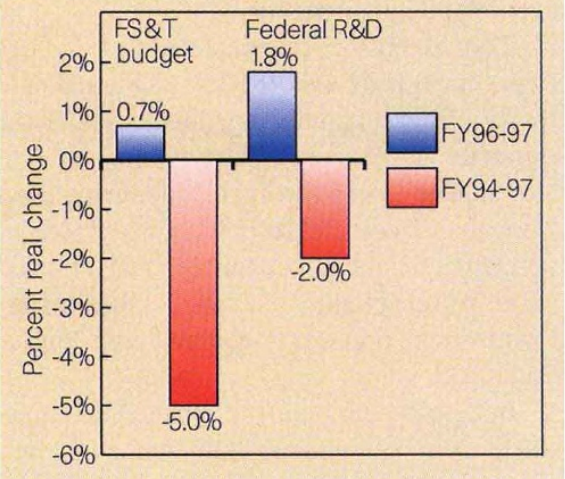

US spending on 'Federal Science and Technology' (FS\&T) has fallen more than official R\&D figures.

nology has been falling. "The president says that he wants to strengthen $R \& D$, and the Congress says the same," he says. "One can gauge from these figures whether officials in the government and Congress are really doing that."

But he does not accuse Clinton or the Congress of duplicity. "I don't think they realize what all their separate decisions have added up to," he says. The object of the exercise, he adds, is to help both branches of the legislature see what is really happening to research spending.

Press and officials of the academy are now briefing administration and congressional officials on their results. Last week, Press met Frank Raines, the new director of the Office of Management and Budget in the White House, and says that Raines "listened intently" to his message.

The academy's assessment shows a steeper decline than the government's measure of R\&D chiefly because the defence department has sharply increased spending on the

\section{Human genome centre receives a leg-up}

[WASHINGTON] The National

Center for Human Genome

Research has been raised to

the status of an institute

within the US National

Institutes of Health $(\mathrm{NHH})$,

expanding its power and

access to funds.

Donna Shalala, Secretary

of Health and Human

Services, renamed the

organization the National

Human Genome Research

Institute on 14 January,

bringing to 18 the number of

institutes at the huge

biomedical agency.

"We're pleased," says

Francis Collins, the institute's

director (pictured below). He says the move recognizes that the genome research centre "has in every way except name been

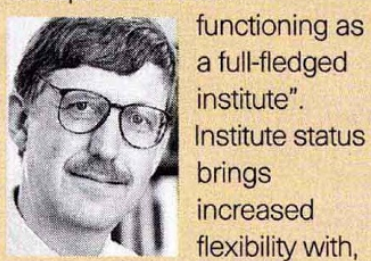

and control over, research grants, and access to congressional funds earmarked for fighting specific diseases.

Congress funded the centre at $\$ 189$ million in 1997. It employs roughly 150 staff and was established in 1989 to carry out the NIIH's role in the Human Genome Project. It has also played a key role in policy discussions through its Working Group on the Ethical, Legal and Social Implications of Human Genome Research

The centre's elevation to institute status initially came in a bill reauthorizing funding for the $\mathrm{NIH}$, which passed the Senate last year. But when the bill was not brought up in the House of Representatives, Shalala took another route, writing to the chairmen of the congressional committees involved with $\mathrm{NIH}$ funding, informing them of her intent to elevate the testing and evaluation of weapons systems - which the academy does not count as $\mathrm{R} \& \mathrm{D}$ - while cutting back on its actual spending on research and development.

Because the assessment includes this 'real' defence R\&D, it also indicates a steeper decline over the past three years than that reported by other assessments which track spending on civil (non-military) research alone.

Press believes that the $\$ 8$ billion or so of 'real' military R\&D is vitally important; for example, it is the predominant source of support for university research in many disciplines, including computer and materials science and most branches of engineering.

In 1995, the academy proposed a measure for FS\&T that would exclude not only military testing and evaluation but also large chunks of non-innovative work at the Department of Energy, and engineering projects at the National Aeronautics and Space Administration (NASA), such as the space station, which costs $\$ 2.1$ billion a year.

But at a meeting last year, analysts persuaded academy officials that the space station had to be included as genuine $R \& D$, because its sole official function is as a platform for science.

"This is purely for the purposes of budgetary analysis - it's not a comment on the worth of the space station," explains Norman Metzger, head of the academy's physical sciences section. "If we took the space station out, it doesn't change the overall trends."

The assessment finds that research funding has grown in only two agencies since 1994 - the health department (whose spending is dominated by the National Institutes of Health), which is up by 8.1 per cent, and the National Science Foundation (NSF), which is up by 1.8 per cent.

As measured by the academy, R\&D spending is down 11.1 per cent at the defence department, 13.8 per cent at the energy department, and 7.3 per cent at NASA. These figures reflect the real spending power of budgets, after allowing for inflation.

According to some budget analysts in Washington, the academy numbers are not new and could readily be gleaned from official sources and the regular assessments performed by the American Association for the Advancement of Science.

But, unlike the association, the academy concentrates on the big picture, and its assessment has been produced much more promptly than the official one, which is conducted by the NSF.

The academy plans to repeat the exercise twice a year, once in response to the president's budget proposal and again after Congress has appropriated a final budget. It will pay for the exercise itself. ColinMacilwain 